In the Red CROSS WORLD

\title{
INTERNATIONAL RED CROSS ASSISTANCE IN INDO-CHINA
}

\section{Republic of Vietnam}

The Netherlands Red Cross medical team working in Chaudoc has completed its mission. The team will not be replaced as it trained local personnel to continue the work of medical aid in the camps.

Two medical teams of the German Red Cross in the Federal Republic of Germany, each composed of one doctor and one nurse, have been working since 7 November. One team is at Lam Dong with I2,000 montagnards and the other is looking after 19,000 displaced persons at Binh Tuy.

IOG has come to the aid of the Red Cross of the Republic of Vietnam with a sum of money for urgent relief supplies to the victims of typhoons "Sarah" and "Thelma", and has launched an appeal to other National Societies for contributions in cash or in kind.

\section{Democratic Republic of Vietnam}

About 3,000 prefabricated dwellings ordered in Finland, Japan and Sweden by the Indo-China Operational Group (IOG) are now either in production or in process of being shipped to the Red Cross of the Democratic Republic of Vietnam. The first batch of I,200 houses from Japan is due to arrive in Haiphong at the end of December.

\section{Provisional Revolutionary Government of the Republic of South Vietnam}

The first consignment of equipment for the 250-bed hospital, consisting of material to a value of about Sw. Frs. 700,000, for the out-patients surgical department, is on its way to Haiphong. 
IN THE RED CROSS WORLD

Laos

The Japanese Red Cross medical team at Pak Lay will be replaced in December by another Japanese team which will also serve for six months in this remote area of Laos where elephants are the standard means of transport for heavy supplies. Teams from the Belgian and British National Societies continue their medical work at Paksane. The northern part of the country is covered by the Swiss team based in Luang Prabang.

\section{Pathet Lao}

Mobile X-ray equipment, medicaments, medical and surgical kits in considerable quantities have now been and are being delivered to the Pathet Lao for aid to the population in the areas they control.

\section{Khmer Republic}

In October, the Swedish Red Cross team started its work in Kompong Cham Hospital. A joint medical team from the National Societies of Denmark and Norway is at work in Kompong Thom.

\section{PROMOTION OF THE RED CROSS IMAGE}

This was the theme of the third meeting of the Heads of National Red Cross, Red Crescent and Red Lion and Sun Societies Information and Public Relations Services which was held at Varna in June I973, and about which International Review published an article in its August issue.

We revert to that meeting here in order to give readers some excerpts, covering four agenda items, from a recent summary record. 